Article

\title{
Nutrient Status in Composts and Changes in Radioactive Cesium Following the Fukushima Daiichi Nuclear Power Plant Accident
}

\author{
Dikkumburage Jasintha Jayasanka ${ }^{1}$, Masakazu Komatsuzaki ${ }^{2, *}$, Yuta Hoshino ${ }^{2}$, Hiroichi Seki ${ }^{2}$ \\ and Mohammad Ismail Moqbal ${ }^{2}$ \\ 1 United Graduate School of Agricultural Science, Tokyo University of Agriculture and Technology, \\ 3-21-1 Chuuo, Ami, Inashiki, Ibaraki 300-0393, Japan; dkjjayasanka@gmail.com \\ 2 Center for Field Science Research \& Education, Ibaraki University, 3-21-1, Ami, Inashiki, Ibaraki 300-0393, \\ Japan; 15am307h@vc.ibaraki.ac.jp (Y.H.); peony3787@yahoo.co.jp (H.S.); mismail350@gmail.com (M.I.M.) \\ * Correspondence: masakazu.komatsuzaki.fsc@vc.ibaraki.ac.jp; Tel.: +81-298-88-8707
}

Academic Editor: Barry D. Solomon

Received: 29 September 2016; Accepted: 12 December 2016; Published: 21 December 2016

\begin{abstract}
Following the Fukushima Daiichi Nuclear Power Plant (FDNPP) accident, the forests in the Fukushima area were highly contaminated with radiocesium $\left({ }^{137} \mathrm{Cs}\right.$ and $\left.{ }^{134} \mathrm{Cs}\right)$. Therefore, there is a need to develop strategies for remediation of the contaminated forests. We assessed changes in radioactive cesium $\left({ }^{134} \mathrm{Cs}\right.$ and $\left.{ }^{137} \mathrm{Cs}\right)$ contamination and nutrient status in composts derived from wood chip, bamboo leaf and bamboo powder using rice bran and wheat meal as sub-materials. Changes in soil properties and Komatsuna (Brassica rapa var. perviridis) growth were also investigated due the application of composts and initial materials at $0,2.5,5$ and $10 \mathrm{~kg} \cdot \mathrm{m}^{-2}$ input levels. Mixing of sub-materials significantly reduced the concentration of radioactive $\mathrm{Cs}$ and improved compost quality. The effectiveness of three composts on soil quality improvement varied depending on their types and rates of applications. Amendments of bamboo leaf composts at $10 \mathrm{~kg} \cdot \mathrm{m}^{-2}$ resulted in the significantly highest soil inorganic $\mathrm{N}$, available $\mathrm{P}$ and exchangeable $\mathrm{K}$ contents. Amendments of final composts also enhanced Komatsuna growth. Furthermore, radioactive Cs contaminations of the Komatsuna plants grown in these composts were below $0.1 \mathrm{~Bq} \cdot \mathrm{kg}^{-1}$. This study may help to remediate the forests contaminated with radiocesium in the Fukushima area while improving the soil organic matter content to enhance soil sustainability.
\end{abstract}

Keywords: wood chip compost; bamboo compost; radioactive Cs contamination; FDNPP accident; rice bran

\section{Introduction}

The content and quality of soil organic matter (SOM) significantly influence soil quality and fertility [1,2]. Soil organic matter improves soil properties, including soil porosity, structure and water retention capacity [3,4]. SOM represents an important source of nutrients for plants [5]. In agricultural lands, SOM is degraded and oxidized faster than it can be naturally replenished, leading to the need for external fertilization. Waste from wood cuttings and plant leaves can be used as a source of SOM; however, this type of waste may contain high levels of toxic constituents, as radioactive materials and heavy metals, which may enter the food chain via plant uptake [6]. The quality of the reactive fraction of the SOM and the physical properties of soils fertilized with woody waste are relatively poor $[7,8]$. Composting of woody and bamboo wastes, however, can result in a high quality source of SOM as a consequence of the accumulation of humus-like substances produced through the biochemical processes occurring during composting. Wood-derived composts also present the advantage of using waste and such by-products as rice bran and wheat meal as source materials. Furthermore, woody 
composts mainly rely on such renewable materials as woody and bamboo chips, rather than on nonrenewable sources. Wood-derived composts are thus expected to enhance soil quality by supplying SOM and enhancing soil microbial activity [9]. Wood and bamboo chip composts are not only rich in SOM, but contain significantly higher concentrations of macro- and micro-nutrients than other compost types $[10,11]$. Consequently, their applications can be linked to enhanced crop yields and long-term improvements in soil quality, thus representing important materials for organic agriculture and eco-farming.

Following the earthquake off the east coast of Japan on 11 March 2011 and the subsequent tsunami along the Fukushima coast, the Fukushima Daiichi Nuclear Power Plant (FDNPP) became severely damaged, resulting in a substantial release of radionuclides from the reactors. After the FDNPP accident, the forests in the Fukushima area received cesium $137\left({ }^{137} \mathrm{Cs}\right)$ fallout ranging between 50,000 and $100,000 \mathrm{~Bq} \cdot \mathrm{m}^{-2}$ [12]. Therefore, the forest in the Fukushima area needed remediation to decrease the radiocesium contaminations. The Japanese government tried to incinerate the trees that were contaminated with radiocesium to reduce the mass of contamination. However, large-scale tree felling and subsequent burning of contaminated woods can produce additional $\mathrm{CO}_{2}$ and ash, which is contaminated with a higher concentration of radiocesium (Figure 1, Plan A). However, this treatment may reduce the organic material in local resources at the same time. Our study attempts to enhance the organic material recycling process if radiocesium contamination in the woods is low (Figure 1, Plan B). Therefore, the proposed system would help in the remediation of the forest, and also, final composts would help in improving the soil organic matter content.

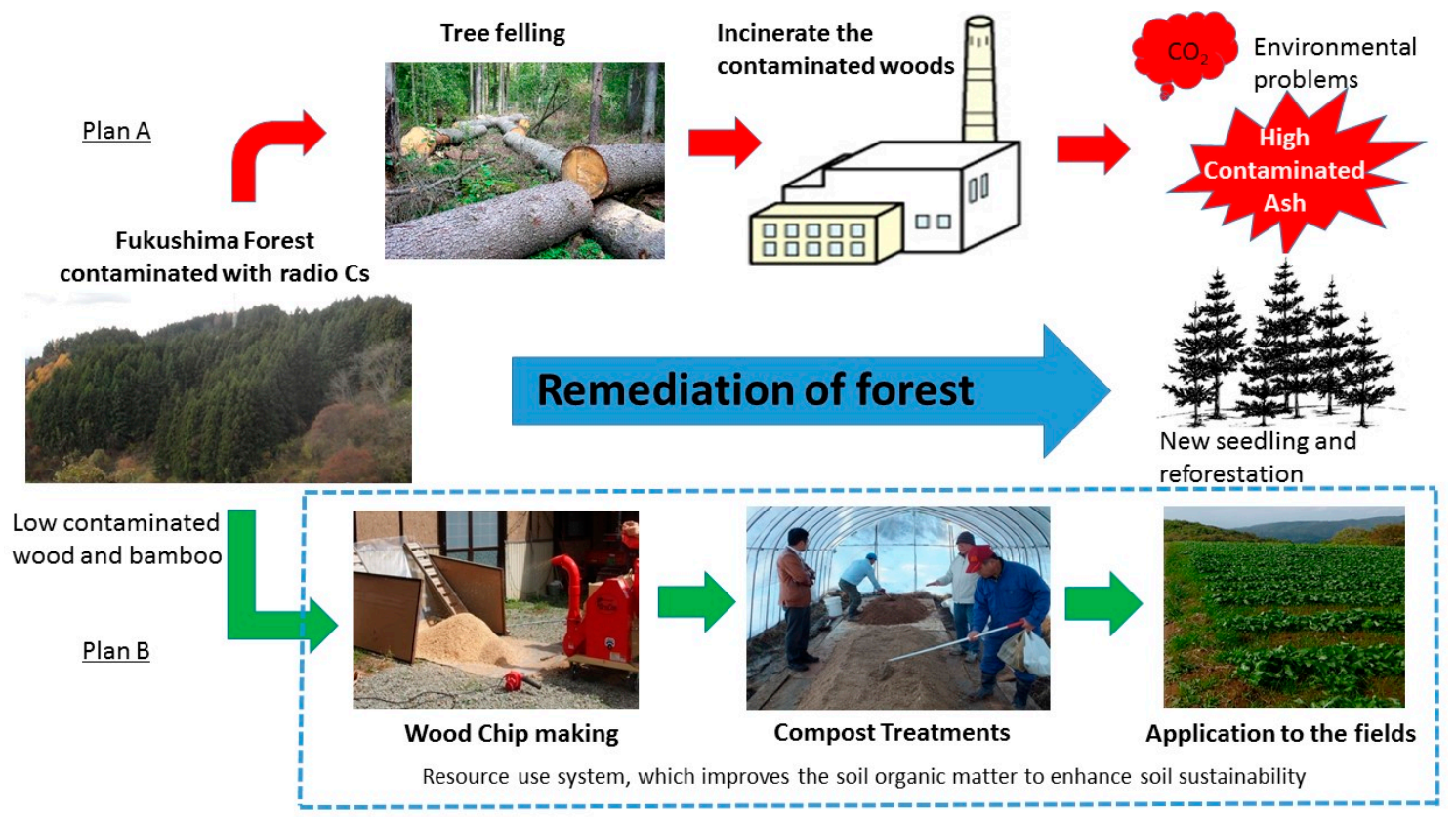

Figure 1. Remediation techniques for forests contaminated with radiocesium.

The objectives of this study were to assess the impacts of rice bran and wheat meal (sub-materials) on radioactive cesium contamination of bamboo and woody compost following the FDNPP accident and to investigate the influence of application rates of woody and bamboo compost on soil properties and crop growth. Furthermore, positive results will provide important information on how to safely resume agricultural work and food production in the Fukushima area. 


\section{Materials and Methods}

\subsection{Compost Materials and Procedure}

We obtained bamboo (Phyllostachys heterocycle f. pubescens) and woody (Quercus acutissima) plant materials from Nihonmatsu city in the Fukushima prefecture. This was $30 \mathrm{~km}$ west from the FDNPP; the deposition densities of total cesium $134\left({ }^{134} \mathrm{Cs}\right)$ and cesium $137\left({ }^{137} \mathrm{Cs}\right)$ in this area were reported to be $60-100 \mathrm{k} \cdot \mathrm{Bq} \cdot \mathrm{m}^{-2}$ [13]. The bamboo and woody materials were crushed to a size of $5 \mathrm{~mm}$ using a chipping machine (KIORITZ KCM281, Yamabiko-corp.co., Tokyo, Japan). Then, these materials were air dried at $25^{\circ} \mathrm{C}$ for $48 \mathrm{~h}$. Consequently, we put $1.2 \mathrm{~kg}$ of wood chip (WC), $0.55 \mathrm{~kg}$ of bamboo leaf (BL) and $0.95 \mathrm{~kg}$ of bamboo powder (BP) in to three separate plastic trays on 24 September 2014. Then, we mixed $0.42 \mathrm{~kg}$ of rice bran and $0.44 \mathrm{~kg}$ of wheat meal with each woody and bamboo material. To initiate the composting process, we added a $2 \%$ molasses solution containing enzymes and microbial inoculums to each compost treatment. Next, each compost was thoroughly mixed by hand in trays. The temperature in each compost treatment was monitored using three thermometers recording data daily. Each compost treatment was mixed and watered once a week. After 45 days of composting, we collected final compost samples from each treatment for further analyses. Samples needed to determine $\mathrm{NO}_{3}{ }^{-}$nitrogen and $\mathrm{NH}_{4}{ }^{+}$nitrogen were used immediately. Samples that were used to determine other nutrients were stored at $4{ }^{\circ} \mathrm{C}$ until prepared for analysis. Then, samples were air-dried, sieved through a $2-\mathrm{mm}$ screen and stored in covered plastic containers at $25^{\circ} \mathrm{C}$.

\subsection{Evaluation of Compost Amendment on Soil Properties and Crop Growth}

To test the performance of different types of composts regarding SOM, nutrient availability, plant growth and Cs contamination, we conducted a greenhouse experiment between November 2014 and March 2015 in Nihonmatsu city in the Fukushima prefecture, Japan $\left(37^{\circ} 5849^{\prime \prime} \mathrm{N}, 140^{\circ} 4311^{\prime \prime} \mathrm{E}\right)$. The experimental site was $30 \mathrm{~km}$ away from the FDNPP. Within the study period, the mean monthly temperature ranged from $5.5^{\circ} \mathrm{C}-30.4{ }^{\circ} \mathrm{C}$, and the average annual rainfall was $1166 \mathrm{~mm}$. The experiment included six randomized treatments and one zero input treatment (soil not supplemented) with three replicates each. The treatments consisted of the addition of WC, BL or BP to the soil as initial material treatments or wood chip compost (WCC), bamboo leaf compost (BLC) or bamboo powder compost (BPC) as compost treatments. Each treatment included $3.5 \mathrm{~kg}$ of Kanuma soil, with an initial mean $\mathrm{pH}$ of 7.1, electrical conductivity (EC) of $0.73 \mathrm{~ms} \cdot \mathrm{cm}^{-1}$, cation exchange capacity (CEC) of $26.2 \mathrm{~mol} \cdot \mathrm{kg}^{-1}$, soil carbon content of $2.6 \%$, organic nitrogen of $0.15 \%,{ }^{134} \mathrm{Cs}$ concentration of $0.8 \mathrm{~Bq} \cdot \mathrm{kg}^{-1}$ and ${ }^{137} \mathrm{Cs}$ concentration of $2.8 \mathrm{~Bq} \cdot \mathrm{kg}^{-1}$. The soil was filled in a 1/5000 Wagner pot $(16 \mathrm{~cm}$ diameter, $20 \mathrm{~cm}$ height), supplemented with 50, 100 or $200 \mathrm{~g}$ of compost (WCC, BLC or BPC) or initial materials (WC, BL or BP) depending on the treatment. We seeded the pots with Komatsuna seeds on 25 November 2014. Five plants were kept per pot after seedling emergence. We harvested the plants after two months and measured plant height, fresh weight and dry weight, as well as the carbon, nitrogen and Cs contents. We also took soil core samples per pot during harvesting to determine the bulk density. In addition, we took soil samples from each pot and let them air-dry before determining their nutrient contents.

\subsection{Measurements of Physical and Chemical Properties}

To determine the level of contamination by radioactive $\mathrm{Cs}$ of the initial materials, composts and soils, the samples were pulverized in a blender (7011BUJ, Asone Co. Ltd., Torrington, CT, USA) before transferring $100 \mathrm{~mL}$ of the powder into $127-\mathrm{mL}$ U-8 polystyrene cylindrical tubes (external size: $5 \mathrm{~cm}$ diameter $\times 6.8 \mathrm{~cm}$ height). ${ }^{137} \mathrm{Cs}$ and ${ }^{134} \mathrm{Cs}$ concentrations were determined using a Ge-semiconductor detector (CANBERRA GC4020: Energy resolution at $1.33 \mathrm{MeV}$ was below $2.0 \mathrm{keV}$ ). The gamma spectra thus obtained were analyzed with a Gamma Explorer (Canberra Industries Inc., Meriden, CT, USA), using a true coincidence summing correction considering the container geometry. Gamma-ray emissions at energies of 604.66 and $661.64 \mathrm{keV}$ for ${ }^{134} \mathrm{Cs}$ and ${ }^{137} \mathrm{Cs}$, respectively, were measured for $1800-7200 \mathrm{~s}$ to achieve reads of at least $10 \mathrm{~Bq} \cdot \mathrm{kg}^{-1}$. The quantitative limits for ${ }^{134} \mathrm{Cs}$ and ${ }^{137} \mathrm{Cs}$ were 
calculated using the method reported by Cooper (1970) [14]. Nine radionuclides mixed activity in alumina at standard volumes (Japan Radioisotope Association, Tokyo, Japan) were used as reference standards. Radio Cs of Komatsuna plants (Brassica rapa var. perviridis) were measured using the same instrument following the guidelines described by the Ministry of Health, Labour and Welfare, Japan (2002) [15]. Quantitative limits for ${ }^{134} \mathrm{Cs}$ and ${ }^{137} \mathrm{Cs}$ in plant samples were each $1 \mathrm{~Bq} \cdot(\mathrm{kg} \text { dry weight })^{-1}$.

Compost temperature was measured using a digital thermometer (TR-71U, T\&D Corporation, Nagano, Japan). Compost moisture contents were determined after oven drying the samples at $65^{\circ} \mathrm{C}$ for $24 \mathrm{~h}$ or until reaching a constant weight [16]. To determine the inorganic nitrogen content, we added $5 \mathrm{~g}$ of soil samples or $2.5 \mathrm{~g}$ of compost samples to $40 \mathrm{~mL}$ of a $1 \mathrm{~mol} \cdot \mathrm{L}^{-1} \mathrm{KCl}$ solution. Nitrate nitrogen levels were then determined using ultraviolet absorption spectrophotometry as described by Yamaki (2003) [17]. Ammonium nitrogen levels were determined using the indophenol blue method, as described by the Soil Environmental Analysis editorial committee (2008) [18]. Exchangeable $\mathrm{K}_{2} \mathrm{O}, \mathrm{MgO}$ and $\mathrm{CaO}$ of soil and compost were determined using an ammonium acetate extraction method [19]. Available phosphorous (P) was determined using Morgan's solution extraction method [20]. To determine the total organic carbon (TOC) and nitrogen content, we oven-dried the soil samples at $105{ }^{\circ} \mathrm{C}$ or $65^{\circ} \mathrm{C}$ for plant samples for $72 \mathrm{~h}$ and measured the contents using a $\mathrm{CN}$ analyzer (JM3000 CN, J-SCIENCE LAB Co. Ltd., Kyoto, Japan). The cation exchange capacity (CEC) of compost and soil was determined using the colorimetric analysis [21]. To determine the CEC, we air-dried the soil or compost sample before soaking them on $1 \mathrm{~mol} \cdot \mathrm{L}^{-1}$ ammonium acetate for $30 \mathrm{~min}$. After removing any excess ammonium salt with an $80 \%$ alcohol solution, we let $1 \mathrm{~mol} \cdot \mathrm{L}^{-1}$ potassium chloride drip over the samples for $30 \mathrm{~min}$. The level of ammonium exchanged was measured using the indophenol blue method, as described by the Soil Environmental Analysis editorial committee (2008) [18]. We used the method described by Culley (1993) [22] to measure the bulk density of compost and soil samples. We used the pycnometer method (Blake and Hartage, 1986) [23] to determine the soil and compost particle density. The $\mathrm{pH}$ was measured in compost and soil water extracts using a pH meter (SG2; made by Mettler Toledo Group; Schwerzenbach, Switzerland) (sample: distilled water of 1:2.5) following the procedures described in Hendershot et al. (1993) [24]. The EC was measured in compost and soil water extracts using an EC meter (D-54; Horiba Co. Ltd., Kyoto, Japan) following the procedures described in Bower and Wilcox (1965) [25].

\subsection{Statistical Analysis}

The data were analyzed using the STAT view (STAT view for windows, Version 5; SAS institute, Cary, NC, USA). To analyze the differences among treatments, we used an analysis of variance (ANOVA) test with a post hoc Tukey's honest significance test for multiple comparisons using a significance of $p<0.05$. Pearson correlation coefficients were used to detect significant correlations between Komatsuna yields and soil properties. Correlations were considered to be significant at $p<0.05$.

\section{Results}

\subsection{Composting from Raw Materials with the Addition of Sub-Materials}

\subsubsection{Variation in Radioactive Cs Concentration}

Table 1 shows the levels of contamination by radioactive Cs of the initial materials and the final compost. Radioactive Cs concentrations in WCC, BLC and BPC were significantly lower than those in WC, BL and BP $(p<0.05)$. Total Cs concentration in WCC, BLC and BPC decreased by $54.8 \%$, $55.5 \%$ and $70.3 \%$, respectively, compared to those in WC, BL and BP (Table 1). The highest level of Cs contamination was detected in WC, and consequently, the level of total radioactive Cs concentration of WCC was significantly higher than that of BLC or BPC $(p<0.05)$. As summarized in Table 1 , the levels of radioactive $\mathrm{Cs}$ contamination in the sub-materials (rice bran and what meal) were significantly lower than those measured in WC, BL or BP. In all cases, ${ }^{137} \mathrm{Cs}$ concentration was significantly higher than ${ }^{134} \mathrm{Cs}$ concentration (Table 1 ). 
Table 1. Level of contamination with radioactive Cs of raw materials and final composts.

\begin{tabular}{ccccccccc}
\hline \multirow{2}{*}{ Materials } & ${ }^{134} \mathbf{C s}$ & Error & ${ }^{137} \mathbf{C s}$ & Error & Total Cs & Error & \multirow{2}{*}{ Moisture \% } \\
\cline { 3 - 7 } & & \multicolumn{7}{c}{$\mathbf{B q} \cdot \mathbf{k g}^{-\mathbf{1}}$} \\
\hline \multirow{2}{*}{ Initial } & Wood chip (WC) & $129.9 \mathrm{~d}$ & 5.5 & $372.4 \mathrm{e}$ & 9.5 & $502.3 \mathrm{e}$ & 15.0 & 13.0 \\
materials & Bamboo leaf (BL) & $16.3 \mathrm{~b}$ & 2.0 & $49.8 \mathrm{c}$ & 3.4 & $66.1 \mathrm{c}$ & 5.4 & 14.0 \\
& Bamboo powder (BP) & $8.2 \mathrm{a}$ & 2.6 & $31.9 \mathrm{~b}$ & 3.0 & $40.1 \mathrm{~b}$ & 5.6 & 11.0 \\
\hline \multirow{2}{*}{ Final } & Wood chip (WCC) & $54.6 \mathrm{c}$ & 3.3 & $172.2 \mathrm{~d}$ & 6.2 & $226.8 \mathrm{~d}$ & 9.5 & 42.0 \\
composts & Bamboo leaf (BLC) & $6.2 \mathrm{a}$ & 0.9 & $23.2 \mathrm{~b}$ & 1.7 & $29.4 \mathrm{~b}$ & 2.6 & 52.0 \\
& Bamboo powder (BPC) & $3.0 \mathrm{a}$ & 0.6 & $8.9 \mathrm{a}$ & 0.9 & $11.9 \mathrm{a}$ & 1.5 & 59.0 \\
\hline
\end{tabular}

Means followed by the different letters in the same column are significantly different $(p<0.05)$.

\subsubsection{Changes in $\mathrm{pH}, \mathrm{EC}$ and $\mathrm{CEC}$}

Final composts did not differ significantly with regard to $\mathrm{pH}(p>0.05)$. In all cases, final $\mathrm{pH}$ values were close to neutral conditions (Table 2). Here, the initial $\mathrm{pH}$ values measured for WC and $\mathrm{BP}$ were 5.2 and 5.4, respectively. However, the $\mathrm{pH}$ had increased by 1.5 and 1.3 units, respectively, in WCC and BPC, respectively. This increment in $\mathrm{pH}$ was probably linked to a release of ammonia through ammonification during composting. In our study, on the other hand, the $\mathrm{pH}$ of BLC decreased by 0.7 units compared to that of BL. This decrease may be related to a reaction with carbon dioxide and the subsequent accumulation of organic acids during composting. To this end, our results show how the addition of sub-materials effectively changed the $\mathrm{pH}$ of WC and BP from slightly acidic to neutral, improving the quality of the final compost.

Table 2. Nutrient content, physical and chemical properties of the raw materials and final composts.

\begin{tabular}{|c|c|c|c|c|c|c|c|c|c|c|c|c|}
\hline & \multirow{2}{*}{ Material } & $\mathrm{C}$ & $\mathbf{N}$ & $\mathbf{P}$ & $K$ & $\mathrm{Mg}$ & $\mathrm{Ca}$ & \multirow{2}{*}{$\mathrm{C} / \mathrm{N}$} & CEC & \multirow{2}{*}{$\mathrm{pH}$} & EC & Bd \\
\hline & & \multicolumn{6}{|c|}{$\%$} & & $\mathrm{cmol} \cdot \mathrm{kg}^{-1}$ & & $\mathrm{~ms} \cdot \mathrm{cm}^{-1}$ & $\mathrm{~g} \cdot \mathrm{cm}^{-3}$ \\
\hline \multirow{2}{*}{$\begin{array}{l}\text { Initial } \\
\text { materials }\end{array}$} & WC & $49.1 \mathrm{~b}$ & $0.25 \mathrm{a}$ & $0.05 \mathrm{a}$ & $0.18 \mathrm{a}$ & $0.033 \mathrm{a}$ & $0.06 \mathrm{~d}$ & $199.5 \mathrm{c}$ & $57.8 \mathrm{~b}$ & $5.2 \mathrm{a}$ & $0.55 \mathrm{a}$ & $0.24 \mathrm{c}$ \\
\hline & $\mathrm{BP}$ & $50.1 \mathrm{c}$ & $0.16 \mathrm{a}$ & $0.07 \mathrm{a}$ & $0.34 \mathrm{a}$ & $0.032 \mathrm{a}$ & $0.04 \mathrm{~b}$ & $321 \mathrm{~d}$ & $28.4 \mathrm{a}$ & $5.4 \mathrm{~b}$ & $1.86 \mathrm{~b}$ & $0.19 \mathrm{~b}$ \\
\hline \multirow{2}{*}{$\begin{array}{l}\text { Final } \\
\text { composts }\end{array}$} & WCC & $45.8 \mathrm{a}$ & $2.65 \mathrm{c}, \mathrm{d}$ & $1.65 \mathrm{~b}$ & $1.48 \mathrm{~b}$ & $0.073 \mathrm{~d}$ & $0.07 \mathrm{e}$ & $17.5 \mathrm{a}$ & $111.3 \mathrm{e}$ & $6.7 \mathrm{c}$ & $7 \mathrm{~d}$ & $0.32 \mathrm{~d}$ \\
\hline & BLC & $45.2 \mathrm{a}$ & $2.98 \mathrm{~d}$ & $1.83 \mathrm{~b}$ & $1.90 \mathrm{c}$ & $0.077 \mathrm{e}$ & $0.04 \mathrm{~b}$ & $15.2 \mathrm{a}$ & $69.8 c$ & $6.7 \mathrm{c}$ & $7.97 \mathrm{e}$ & $0.2 \mathrm{~b}$ \\
\hline
\end{tabular}

Means followed by the different letters in the same column are significantly different $(p<0.05)$; CEC: cation exchange capacity; Bd: bulk density; EC: electrical conductivity.

Our results show how EC significantly increased in WCC, BLC and BPC compared to that in WC, BL and BP $(p<0.05)$ (Table 2). In this study, the highest EC value was observed in BLC, which was $76 \%$ higher than that measured in BL. Among the final composts, the lowest EC value was observed in WCC; however, the EC of WC was also lower than that of BL and BP. We did not find a significant difference on EC between BLC and BPC $(p>0.05)$. The CEC of the final composts were significantly higher $(p<0.05)$ than those of the initial materials (Table 2). CEC of WCC, BLC and BPC were increased by $92 \%, 36.5 \%$ and $250 \%$ compared to those of WC, BL and BP. The highest level of CEC was observed in WCC, while the lowest level was detected in BLC.

\subsubsection{Changes in TOC, $\mathrm{TN}$ and $\mathrm{C} / \mathrm{N}$ Ratio}

TOC content decreased significantly in the final composts compared to the raw materials. Total nitrogen (TN) content, on the other hand, was significantly higher in the final composts compared to those of the initial materials (Table 2). This negative correlation created a significant reduction in the $\mathrm{C} / \mathrm{N}$ ratio in all of the final composts compared to those of the raw materials. Here, TOC content in WC, BL and BP decreased by $6.7 \%, 8.3 \%$ and $8.4 \%$, respectively, compared to WCC, BLC and BPC. On the other hand, TN content of WCC, BLC and BPC increased by 10-, 3- and 15-fold, respectively, compared to WC, BL and BP. In addition, we found no significant differences in TOC and 
$\mathrm{C} / \mathrm{N}$ ratios among WCC, BLC and BPC. The $\mathrm{C} / \mathrm{N}$ ratios of the final composts were $<20$, indicating that the composts had stabilized (Table 2).

\subsubsection{Changes in Nutrient Content}

In this study, available $\mathrm{P}$ and exchangeable $\mathrm{K}, \mathrm{Mg}$ and $\mathrm{Ca}$ contents in WCC, BLC and BPC increased significantly compared to those of WC, BL and BP $(p<0.05)$ (Table 2). Available P contents in WCC, BLC and BPC increased by 30-, 20- and 24-fold, respectively, compared to those of WC, BL and BP. However, we did not observe any significant differences for available $\mathrm{P}$ content among the three final composts. Exchangeable K contents in WCC, BLC and BPC increased by 8-, 1.5- and 5-fold, respectively, compared to those of WC, BL and BP. Exchangeable K content was significantly lower in WCC compared to those of BLC and BPC. Among the final composts, BLC showed a significantly higher $\mathrm{Mg}$ content than the rest, while WCC showed the highest significant $\mathrm{Ca}$ content.

Ammonium-nitrogen $\left(\mathrm{NH}_{4}{ }^{+}-\mathrm{N}\right)$ was significantly lower than nitrate-nitrogen $\left(\mathrm{NO}_{3}{ }^{-}-\mathrm{N}\right)$ of the final composts $(p<0.05)$ (Figure 2a). In addition, $\mathrm{NO}_{3}{ }^{-}-\mathrm{N}$ was highest in BLC and lowest in WCC. We found no significant differences in $\mathrm{NH}_{4}{ }^{+}-\mathrm{N}$ among the final composts $(p>0.05)$. In our experiment, final $\mathrm{NH}_{4}{ }^{+} / \mathrm{NO}_{3}{ }^{-}$ratios were $<0.5$ (Figure $2 \mathrm{~b}$ ).
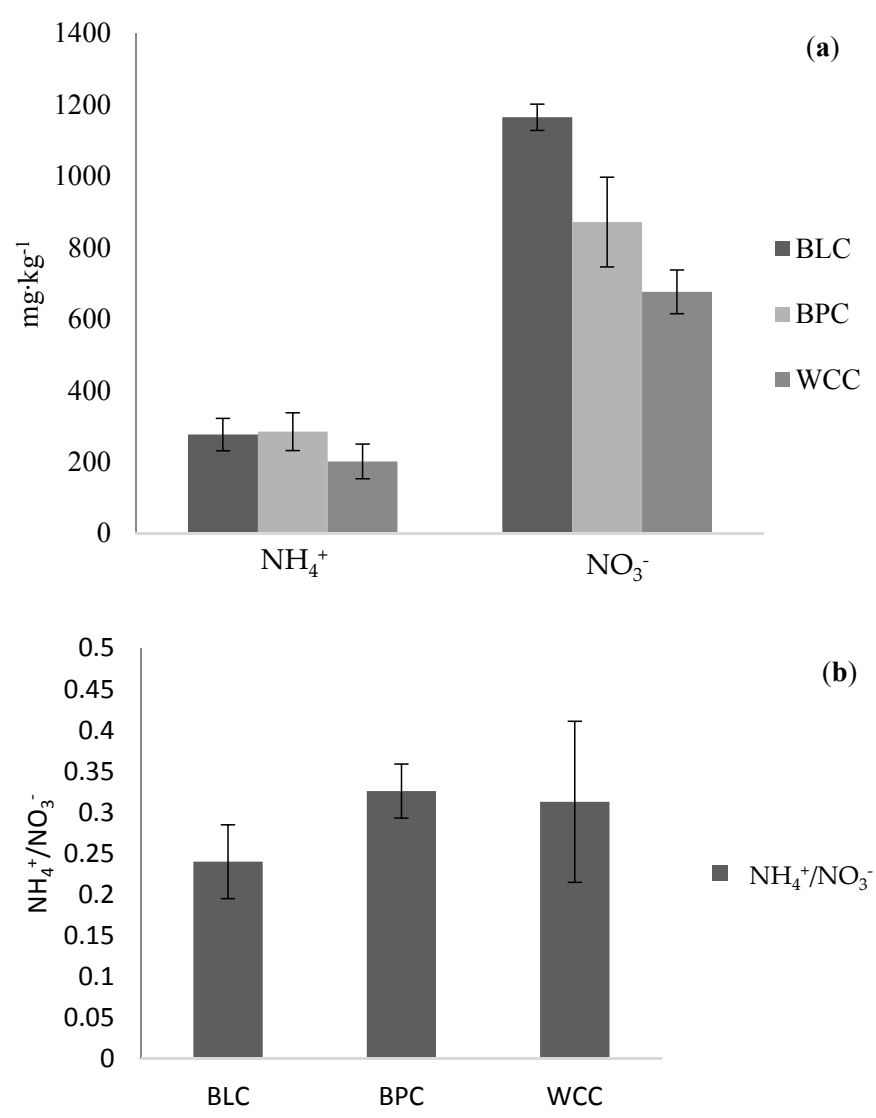

Figure 2. $\mathrm{NH}_{4}{ }^{+}-\mathrm{N}$ and $\mathrm{NO}_{3}{ }^{-}-\mathrm{N}$ concentrations of final composts (a); and $\mathrm{NH}_{4}{ }^{+} / \mathrm{NO}_{3}{ }^{-}$ratios of the final composts (b).

\subsection{Changes in Soil Properties through Compost and Compost-Raw Material Amendment}

For some treatments, we found that compost or raw material amendment significantly influenced radioactive Cs concentrations (Figure 3). Amendments with BLC, BPC, BL and BP did not significantly increase radioactive $\mathrm{Cs}$ concentration in the soil compared to the zero input treatment. However, radioactive Cs concentrations were significantly higher in the pots amended with WCC and WC, compared to the zero input treatment, for all input levels. Furthermore, radioactive Cs concentrations 
in soils amended with WCC were significantly lower than those in WC for all input levels $(p<0.05)$. The highest soil radioactive Cs concentration was measured in soils amended with WC at the $10 \mathrm{~kg} \cdot \mathrm{m}^{-2}$ input level. Thus, radioactive Cs concentration in this treatment was nine-times higher than that observed in the zero input treatment.

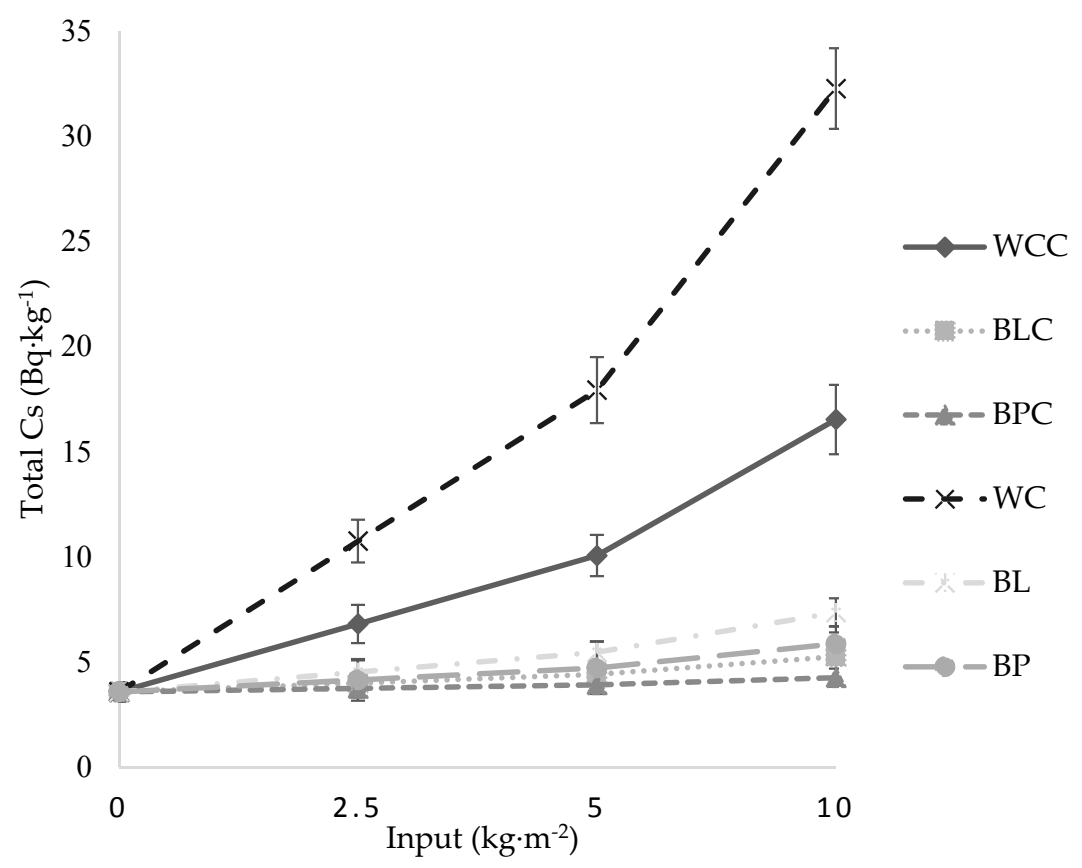

Figure 3. Soil radioactive Cs content in relation to amendments with raw materials and final composts.

Type of amendment and input level significantly changed the soil C, N, P and K contents (Table 3). Amendment with compost significantly increased inorganic nitrogen content in soils compared to amendment with raw materials for all input levels $(p<0.05)$ (Figure $4 a)$. In addition, soil inorganic nitrogen content increased with the amount of compost applied (Figure 4a). Thus, amendment with BLC at $10 \mathrm{~kg} \cdot \mathrm{m}^{-2}$ resulted in the highest soil inorganic nitrogen content measured, which was $206 \%$ higher than the zero input treatment. Amendment with final composts significantly increased available $\mathrm{P}$ and exchangeable $\mathrm{K}$ concentrations compared to amendments with raw materials at all input levels $(p<0.05)$ (Figure $4 \mathrm{~b}, \mathrm{c})$. Soil available $\mathrm{P}$ and exchangeable $\mathrm{K}$ increased with the amount of compost applied (Figure $4 \mathrm{~b}, \mathrm{c}$ ). Applying BLC at $10 \mathrm{~kg} \cdot \mathrm{m}^{-2}$ resulted in an increase in soil available P concentration of 500\% compared to that of the zero input treatment, the highest increment measured in our experiment. Applying BLC at $10 \mathrm{~kg} \cdot \mathrm{m}^{-2}$ resulted in a $748 \%$ increase in soil exchangeable $\mathrm{K}$ compared to that of the zero input treatment, the highest increment measured in our experiment.

Table 3. Analyses of variance and levels of significance for soil nutrients and physical properties among compost treatments, compost materials and input levels. The analysis did not include the zero input treatment.

\begin{tabular}{|c|c|c|c|c|c|c|c|c|c|c|c|}
\hline \multirow{2}{*}{ Factor } & \multirow{2}{*}{ df } & $\mathrm{NH}_{4}-\mathrm{N}$ & $\mathrm{P}_{2} \mathrm{O}_{5}$ & $\mathrm{~K}_{2} \mathrm{O}$ & $\mathrm{CaO}$ & $\mathbf{N}$ & $\mathrm{C}$ & Porosity & \multirow{2}{*}{$\mathbf{C} / \mathbf{N}$} & \multirow{2}{*}{$\mathrm{pH}$} & \multirow{2}{*}{$\begin{array}{c}\mathrm{Bd} \\
\mathrm{g} \cdot \mathrm{cm}^{-3}\end{array}$} \\
\hline & & \multicolumn{4}{|c|}{$\mathrm{mg} \cdot \mathrm{kg}^{-1}$} & \multicolumn{3}{|c|}{$\%$} & & & \\
\hline Material (M) & 2 & $<0.0001$ & 0.0774 & $<0.0001$ & 0.028 & 0.0118 & $<0.0001$ & 0.1174 & $<0.0001$ & $<0.0001$ & 0.1174 \\
\hline Type (T) & 1 & $<0.0001$ & $<0.0001$ & $<0.0001$ & 0.128 & $<0.0001$ & $<0.0001$ & 0.0043 & $<0.0001$ & $<0.0001$ & 0.0043 \\
\hline Input level (L) & 2 & $<0.0001$ & $<0.0001$ & $<0.0001$ & 0.942 & $<0.0001$ & $<0.0001$ & 0.0003 & $<0.0001$ & 0.0094 & 0.0003 \\
\hline $\mathrm{M} \times \mathrm{T}$ & 2 & 0.0016 & $<0.0001$ & 0.0002 & 0.394 & 0.9451 & $<0.0001$ & 0.1844 & $<0.0001$ & $<0.0001$ & 0.1844 \\
\hline $\mathrm{M} \times \mathrm{L}$ & 4 & $<0.0001$ & 0.0132 & $<0.0001$ & 0.843 & 0.3153 & 0.0008 & 0.0798 & 0.0001 & 0.001 & 0.0798 \\
\hline $\mathrm{T} \times \mathrm{L}$ & 2 & $<0.0001$ & $<0.0001$ & $<0.0001$ & 0.023 & $<0.0001$ & 0.0003 & 0.7238 & $<0.0001$ & $<0.0001$ & 0.7238 \\
\hline $\mathrm{M} \times \mathrm{T} \times \mathrm{L}$ & 4 & 0.017 & 0.3673 & 0.1668 & 0.349 & 0.973 & 0.0008 & 0.8572 & $<0.0001$ & 0.1926 & 0.8572 \\
\hline
\end{tabular}



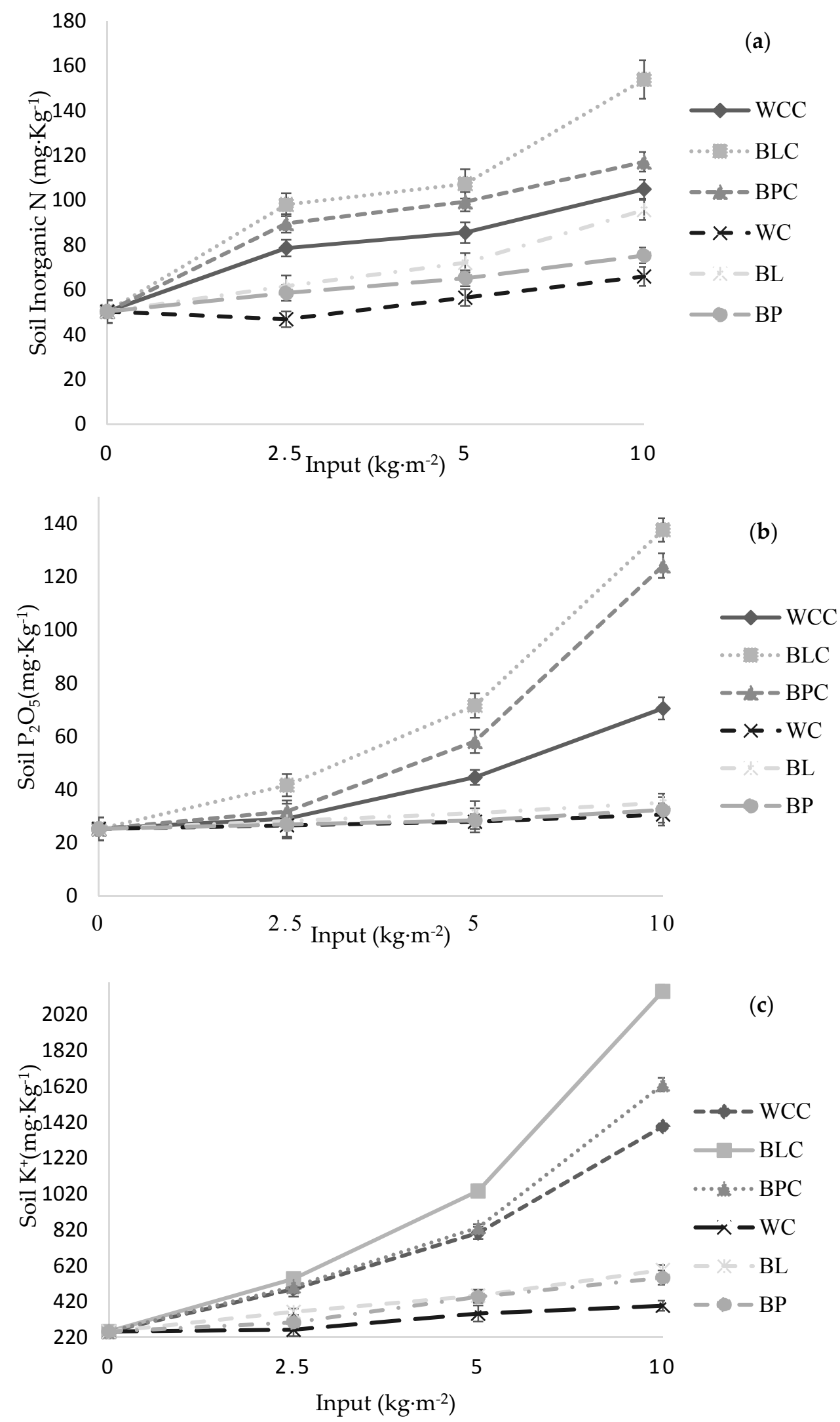

Figure 4. Soil inorganic nitrogen (a); available $\mathrm{P}(\mathbf{b})$ and exchangeable $\mathrm{K}$ content (c) in relation to amendments with raw materials and final composts. 


\subsection{Influence of Compost Amendment on Crop Growth}

Radioactive Cs concentrations in Komatsuna plants were below $0.1 \mathrm{~Bq} \cdot \mathrm{kg}^{-1}$ in all treatments. Compost material and type of the amendment significantly changed plant height, dry matter, carbon and nitrogen contents (Table 4). Plant growth in BLC and BPC amendments, at all input levels, showed increased values of dry plant matter values compared to that of the zero input treatment. For WCC, on the other hand, a significant increase was only observed at the $10 \mathrm{~kg} \cdot \mathrm{m}^{-2}$ input level (Figure $5 \mathrm{a}$ ). Plant growth in soils amended with BLC at $10 \mathrm{~kg} \cdot \mathrm{m}^{-2}$ showed a $109 \%$ increase in dry matter compared to that of the zero input treatment. In this study, plant biomass increased with the increase in compost input level. On the other hand, Komatsuna plant dry matter decreased with the increase in the input level of raw materials (Figure 5a). In addition, the levels of soil inorganic N, available $\mathrm{P}$ and exchangeable $\mathrm{K}$ on the compost treatments (WCC, BLC and BPC) were correlated with plant yield $\left(r^{2}=0.422,0.364\right.$ and 0.195, respectively; $\left.p<0.05\right)$ (Figure 6a-c).
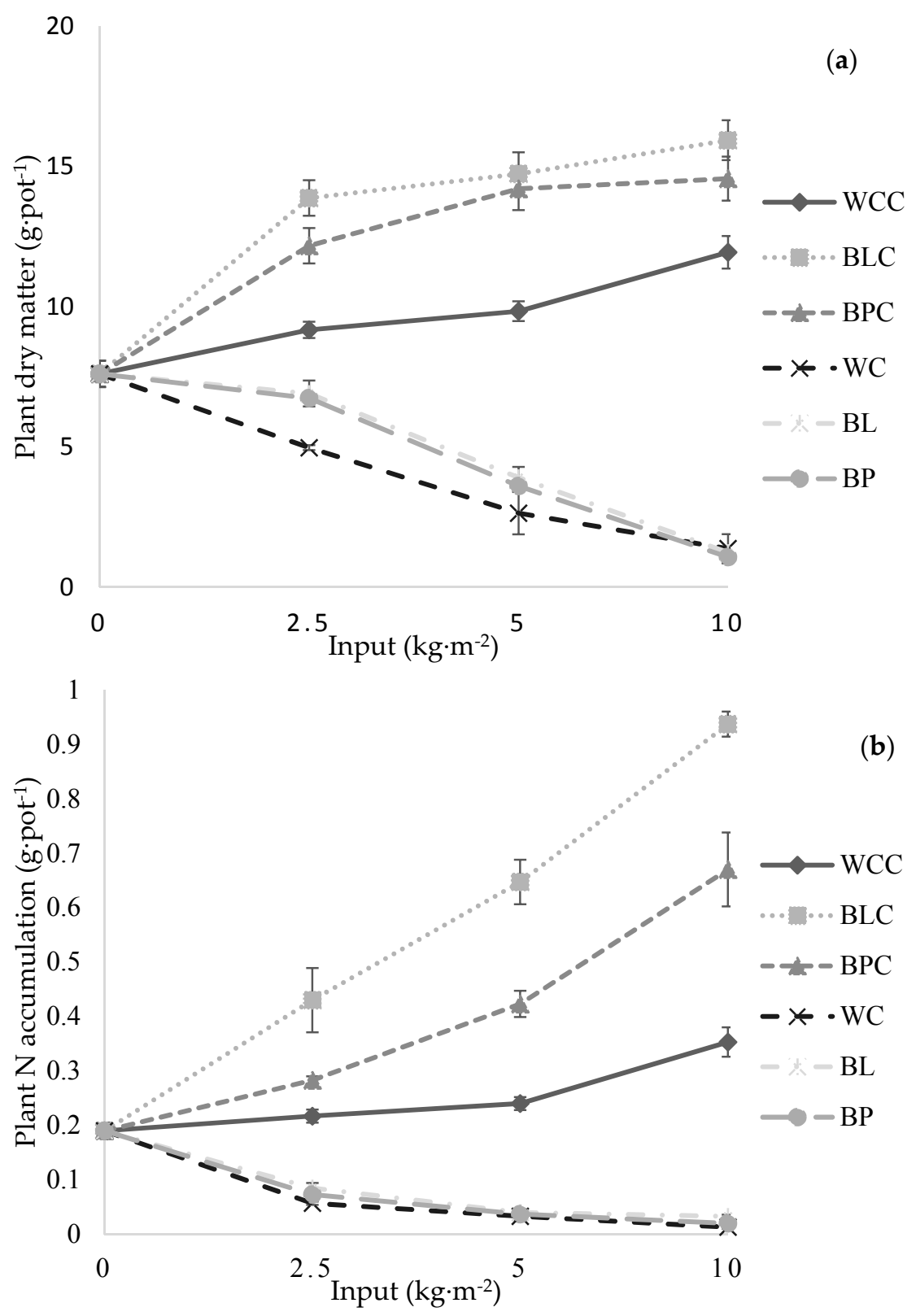

Figure 5. Plant dry matter (a) and plant $\mathrm{N}$ accumulation content $(\mathbf{b})$ in relation to amendments with raw materials and final composts. 

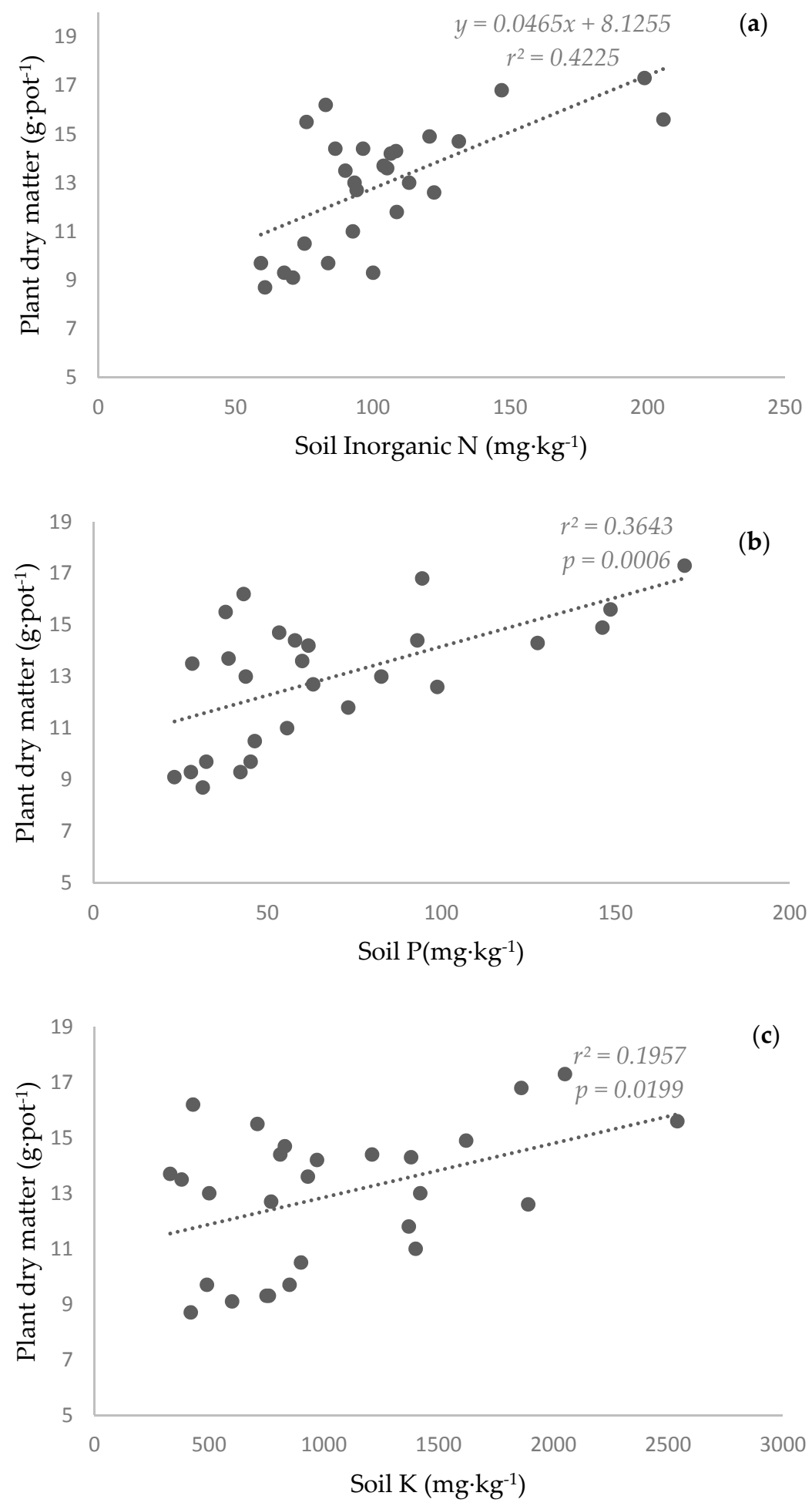

Figure 6. Correlation between soil inorganic N content and plant dry matter content (a); correlation between soil available P content and plant dry matter content $(\mathbf{b})$; correlation between soil exchangeable $\mathrm{K}$ content and plant dry matter content $(\mathbf{c})$.

As depicted in Figure 5b, the plant's $\mathrm{N}$ accumulation increased with the increase in compost input level. Application of BLC significantly increased $\mathrm{N}$ accumulation compared to the zero input treatment for all input levels $(p<0.05)$. For pots amended with BPC, on the other hand, significant increments were observed only at the $5 \mathrm{~kg} \cdot \mathrm{m}^{-2}$ and $10 \mathrm{~kg} \cdot \mathrm{m}^{-2}$ input levels. For WCC, N accumulation was 
significantly higher than that of the zero input treatment at the $10 \mathrm{~kg} \cdot \mathrm{m}^{-2}$ input level only. The highest level of $\mathrm{N}$ accumulation was observed in the pots amended with BLC at $10 \mathrm{~kg} \cdot \mathrm{m}^{-2}$, which showed a $393 \%$ of increment in N compared to that of the zero input treatment. As shown in Figure 5b, WC, BL and $\mathrm{BP}$ amendments significantly decreased $\mathrm{N}$ accumulation compared to the zero input treatment for all input levels $(p>0.05)$. Application of WC at the $10 \mathrm{~kg} \cdot \mathrm{m}^{-2}$ rate resulted in the lowest level of $\mathrm{N}$ accumulation observed, which was $93 \%$ lower than that of the zero input treatment.

Table 4. Analyses of variance and levels of significance for Komatsuna biomass and nutrients among compost treatments, compost materials and input levels. The analysis did not include the zero input treatment.

\begin{tabular}{ccccccccc}
\hline Factor & df & Plant Height $(\mathbf{c m})$ & Fresh Weight (g) & Dry Weight (g) & $\mathbf{N} \%$ & C\% & C/N & Root Weight (g) \\
\hline Material (M) & 2 & $<0.0001$ & $<0.0001$ & $<0.0001$ & $<0.0001$ & 0.007 & 0.0027 & 0.3671 \\
Type (T) & 1 & $<0.0001$ & $<0.0001$ & $<0.0001$ & $<0.0001$ & $<0.0001$ & $<0.0001$ & $<0.0001$ \\
Input level (L) & 2 & 0.1304 & 0.3476 & 0.0054 & $<0.0001$ & 0.1118 & 0.0004 & $<0.0001$ \\
$\mathrm{M} \times \mathrm{T}$ & 2 & 0.018 & $<0.0001$ & $<0.0001$ & $<0.0001$ & 0.0782 & 0.0006 & 0.1348 \\
$\mathrm{M} \times \mathrm{L}$ & 4 & 0.2144 & 0.4803 & 0.3935 & 0.0012 & 0.6545 & 0.0001 & 0.2971 \\
$\mathrm{~T} \times \mathrm{L}$ & 2 & $<0.0001$ & $<0.0001$ & $<0.0001$ & $<0.0001$ & 0.0439 & 0.0022 & $<0.0001$ \\
$\mathrm{M} \times \mathrm{T} \times \mathrm{L}$ & 4 & 0.1635 & 0.5984 & 0.8124 & 0.0089 & 0.46 & 0.0014 & 0.0187 \\
\hline
\end{tabular}

\section{Discussion}

\subsection{Influence of Sub-Materials on Radiocesium Levels and Chemical Properties of Bamboo and Woody Composts}

The level of Cs content in each of the materials did not change throughout the composting process. However, the concentration of radioactive Cs in the source rice bran and wheat meal was very low. Thus, the observed decrease in radioactive $C$ s concentration was achieved by mixing highly contaminated raw materials (WC, BL or BP) with low contaminated sub-materials (rice bran or wheat meal). The higher moisture content of the final compost compared to the raw materials would also influence Cs concentration. In addition, the greater ${ }^{137} \mathrm{Cs}$ concentration may be related to the longer half-life of ${ }^{137} \mathrm{Cs}$ compared to ${ }^{134} \mathrm{Cs}$. Our results suggest that radioactive Cs contamination can be successfully reduced through the addition of low-contaminated sub-materials, even for highly contaminated raw composting materials. Thus, our study shows that composting can be used as a viable strategy to remediate and reclaim sites contaminated with radionuclides. However, the authors suggested avoiding the use of organic materials highly contaminated with radioactive Cs in soils to prevent its accumulation in crops. To the extent of our knowledge, there are no studies describing the variation in Cs concentration before and after composting. Some previous research has assessed the transfer of radioactive Cs from soil to crops following soil fertilization with contaminated organic materials [26]. Alexakhin (1993) [27] also reported that agricultural practices could effectively mitigate the radiological consequences of the Chernobyl accident in pasture grasslands. Entry et al. (2001) [28] reported that adding organic matter to the soil can initiate remediation and reclamation of contaminated soils.

The results of this study suggested that the addition of sub-materials effectively changed the $\mathrm{pH}$ of WC and BP from slightly acidic to neutral, thereby improving the quality of the final compost. According to previous research, the optimal $\mathrm{pH}$ value for green waste compost is neutral [29], and it is closely related to microbial activity during composting [30]. A neutral $\mathrm{pH}$ enhances the water solubility of nutrients available for plant uptake, in particular that of $\mathrm{P}$ and many micronutrients [31]. In addition, previous research has reported an optimal $\mathrm{pH}$ of finished compost in the range of 7.5-8 [32]. According to Mulligan (2005) [33], an increase in microbial activity would also increase the decomposition rate of readily degradable organic nitrogen, increase the amount of ammonia released and lead to a sharp increase in $\mathrm{pH}$. The later phase of the secondary fermentation is associated with a reduction of readily degradable organic matter and a decline in the decomposition rate; at this point, the $\mathrm{pH}$ values decreased in all treatments and subsequently remained stable [30]. This decrease in $\mathrm{pH}$ could be related 
to an increase in nitrification experienced toward the end of the composting process, which acidifies the environment [34].

In our study, we prevented mineral salt leaching and precipitation by frequently mixing the compost and using plastic trays as experimental plots. Thus, our findings suggest that mixing the materials during composting enhances the degradation process by supplying sufficient nitrogen to enrich the composting process. Our results regarding EC followed those reported by Li et al. (2012) [35], who composted pig manure using bentonite. Liu and Price (2011) [36] also reported an increase in EC by $107 \%$ in compost derived from spent coffee ground compared to the raw material. As described by Larney et al. (2008) [10], the EC of WC is 10-times lower than that of straw EC. As described by Villar et al. (1993) [37], the mineralization of organic matter and the subsequent release of soluble salts, such as phosphates and potassium, during the composting process would be the principal reason behind the observed increase in EC. In general, EC could be higher in the final product than in the initial mixture because of the release of soluble salts; however, it could also decrease because of ammonia volatilization and mineral salt leaching and precipitation $[38,39]$.

Adding rice bran and wheat meal to the compost increased the charge density per unit surface area by enhancing organic matter oxidation. Our results showed that adding sub-materials to the compost increased $\mathrm{TN}$ content and decreased the $\mathrm{C} / \mathrm{N}$ ratio, enhancing the decomposition rate. According to Harada and Inoko (1980) [40], compost maturity is characterized by a CEC $>60.0 \mathrm{cmol} \cdot \mathrm{kg}^{-1}$, suggesting that all of our final composts had reached maturity. A similar reduction in TOC content, associated with an increase in TN content, has been previously reported by Zhang and Sun (2014) [41]. These trends have been previously reported in many previous composting studies and are related to a rapid decomposition of organic matter [39]. These results follow those by Fang et al. (1999) [42], who reported that, by the end of the composting period, the $\mathrm{C} / \mathrm{N}$ ratio was below 20 for mature composts. Furthermore, Rodriguez-Kabana et al. (1987) [43] reported that the $\mathrm{C} / \mathrm{N}$ ratio of organic amendments should remain within the range of 12-25 to avoid phytotoxicity. Thus, our results suggest that our composts were suitable as a soil amendment.

Our results indicated that the addition of sub-materials increased the rate of mineralization of essential nutrients in the compost, as nutrient content was overall enhanced in WCC, BLC and BPC compared to that of WC, BL and BP. Since these nutrients are non-volatile, they tend to remain in the compost; therefore, their increase in concentration is a reflection of the rate of decomposition of organic matter during composting. The results of this composting study are in agreement with Mondonca Costa et al. (2015) [44], who observed a significant increment in nutrient content in the final compost compared to the raw materials. The same observation was found by Nishanth and Biwas (2008) [45] in a study on the effect of adding rock phosphate to treated compost. Liu and Price (2011) [36] also observed an increase in macro- and micro-nutrient concentrations in the final compost compared to the raw materials.

In general, the aeration rate and turning frequency influence the nitrogen dynamics through volatilization and leaching. However, the low $\mathrm{NH}_{4}{ }^{+}$contents and high $\mathrm{NO}^{-}$contents measured in the final composts in our study indicated that the addition of sub-materials created a favorable microenvironment for nitrifying bacteria, which convert ammonia to nitrate, helping $\mathrm{N}$ retention in the compost. Similar results have been reported in composting studies using sewage sludge, cattle manure and pig manure [42,46,47]. According to Das et al. (2011) [48], the $\mathrm{NH}_{4}{ }^{+} / \mathrm{NO}_{3}{ }^{-}$ratio is a good indicator of compost maturity. In our experiment, final $\mathrm{NH}_{4}{ }^{+} / \mathrm{NO}^{-}$ratios were $<0.5$ (Figure $2 \mathrm{~b}$ ), suggesting that all final composts had reached maturity.

\subsection{Changes in Soil Properties through Compost Amendment}

Our results showed that compost amendment reduced soil radioactive Cs concentration compared to amendments with raw materials. In addition, the influence of the compost on the soil Cs concentration was dependent on the type and the level of input. However, amendment with raw materials resulted in significantly high soil Cs concentrations because of their high contamination 
with radioactive Cs. Harada et al. (2014) [26] showed that radioactive Cs concentration significantly increases after soil amendment with contaminated cattle farmyard manure. Thus, adding sub-materials, such as rice bran and wheat meal, emerged as an effective strategy to control soil radioactive Cs concentration following the FDNPP accident. In our study, final composts exhibited significantly lower radioactive $\mathrm{Cs}$ concentration than the raw materials; therefore, the application of final compost could be a viable strategy to reduce soil radioactive Cs concentrations following the FDNPP accident.

Comparatively lower organic $\mathrm{C}$ content in final composts compared to the raw materials supply evidences regarding the high nutrient availability in the compost amendment compared to the amending with raw materials. Thus, these results suggested that compost amendments can increase the concentration of soil nutrients available for plant growth, compared to amendments with raw materials. The results of our study follow those reported by Chaoui et al. (2003) [49], who observed an increase in soil inorganic nitrogen after compost amendment. Mylavarapu and Zinati (2009) [50] also reported that amending soil with compost significantly increased soil nitrogen concentrations. The lower $\mathrm{C} / \mathrm{N}$ ratio of the final composts versus the raw materials indicates that the compost would be an effective source of $\mathrm{N}$ through rapid $\mathrm{N}$ mineralization reactions. Overall, our results indicated that compost amendment can increase soil inorganic nitrogen content compared to amending with raw materials. These results follow those reported by Courtney and Mullen (2008) [51], who showed an increase of available $\mathrm{K}, \mathrm{Ca}, \mathrm{Mg}$ and $\mathrm{Na}$ in soils following compost amendments.

\subsection{Compost Amendment Influence in Crop Growth}

In this study, plant biomass increased with the compost input level, mainly due to an increment in nutrient availability with the increase in the amount of compost applied. The addition of sub-materials also enhanced compost nutrient content. The reduction in plant biomass in soils amended with raw materials was mainly due to low nutrient availability in these initial materials and the low concentration of decomposed products. Harada et al. (2014) [26] demonstrated that the effects of using contaminated farm yard manure on the concentration of radioactive $C s$ found in crops depend not only on the contamination level, but also on factors, such as soil exchangeable $\mathrm{K}_{2} \mathrm{O}$ content. Furthermore, Hoshino et al. (2015) [52] reported that the ecological behavior of radioactive Cs is influenced by the amount of clay minerals present in the soil. Thus, the low radioactive Cs concentrations found in Komatsuna plants in this study could be related to these two effects. In addition, composts may directly increase the quantity of nutrient available to plants or indirectly through its effects on the CEC [53,54]. The results of this study follow those reported by Courtney and Mullen (2008) [51], who found that barley grain yield increased when the amendment rates of spent mushroom compost were increased. Cherif et al. (2009) [55] also reported that compost amendments significantly enhanced wheat grain yield and that plots amended with higher compost nutrient contents also showed the highest wheat yields.

The higher levels of $\mathrm{N}$ accumulation linked to compost amendments may be related to the direct input of $\mathrm{N}$ to the soil through the compost. The addition of sub-materials also effectively enhanced the level of $\mathrm{N}$ input through compost compared to $\mathrm{WC}, \mathrm{BL}$ and BP alone. Our results show a strong significant correlation between the plant's $\mathrm{N}$ and soil inorganic $\mathrm{N}$ content $\left(r^{2}=0.634, p<0.05\right)$ in compost treatments. Thus, compost amendments can considerably influence mineral $\mathrm{N}$ dynamics in soil. According to Keeling et al. (2003) [56], $\mathrm{N}$ is the key nutrient for plant growth, and yields are usually strongly related to $\mathrm{N}$ supply.

\section{Conclusions}

Mixing of rice bran and wheat meal with highly contaminated raw materials effectively decreased the radiocesium contamination of the final compost by approximately $50 \%$ and was able to secure the contamination levels below the governmental legislation limits in Japan. Therefore, there is a high possibility to use all three final composts as a soil ameliorant. The three final composts differed in composition, in particular in terms of nutrients and the level of radioactive contamination. Therefore, 
their impact on soil properties varied according to the type and the rate of application. However, overall, application of the final compost reduced contamination levels of Cs, raised levels of nutrients, the organic status of soil and enhanced the Komatsuna plant growth. Among three final composts, BLC most effectively enhanced the availability of soil N, P and K levels. Fukushima farmers may adopt this system to help remediate contaminated bamboo forests, while opening the possibility of using wood and bamboo contaminated with radioactive Cs as composting material.

Acknowledgments: Most sincere gratitude and appreciation are extended to the Higher Education Ministry Japan (Monbukagakusho) for the financial support granted to conduct this study. The authors express their sincere gratitude to the students and staff of the Field Science Center, Faculty of Agriculture Ibaraki University, for their assistance given throughout the period of study. We would also like to thank Yuukinosato Towa Furusato Zukuri Kyogikai for field research assistance. This study was supported by a grant from the Ibaraki University for earthquake disaster reconstruction and the Interorganization Atomic Energy Research Program between the Japan Atomic Energy Agency and universities.

Author Contributions: Dikkumburage Jasintha Jayasanka, who is a Ph.D. student at Tokyo University of Agriculture and Technology (TUAT), performed this research, analyzed the data and wrote the manuscript. Masakazu Komatsuzaki is a professor at the Center for Field Science Research \& Education, Ibaraki University, who designed this research and provided his valuable opinions during the manuscript writing. Yuta Hoshino, Hiroichi Seki and Mohammad Ismail Moqbal are master students in Komatsuzaki's lab, who gave their contributions in data collection and the preparation of material. All authors read and approved the final manuscript.

Conflicts of Interest: The authors declare no conflict of interest.

\section{References}

1. Stevenson, F.J. Humus Chemistry: Genesis, Composition, Reactions; John Wiley \& Sons: San Francisco, CA, USA, 1994.

2. Reeves, D.W. The list of soil organic matter in maintaining soil quality in continuous cropping systems. Soil Tillage Res. 1997, 43, 131-167. [CrossRef]

3. Oades, J.M. Soil organic matter and structural stability: Mechanisms and implications for management. Plant Soil 1984, 76, 319-337. [CrossRef]

4. Etana, A.; Hakansson, I.; Swain, E.; Bucas, S. Effects of tillage depth on organic coal content and physical properties in five Swedish soils. Soil Tillage Res. 1999, 52, 129-139. [CrossRef]

5. Sanchez, P.A.; Palm, C.A.; Szott, L.T.; Cuevas, E.; Lal, R. Organic input management in tropical agroecosystems. Dyn. Soil Org. Matter Trop. Ecosyst. 1989, 25, 152.

6. Wuana, R.A.; Okieimen, F.E. Heavy metals in contaminated soils: a review of sources, chemistry, risks and best available strategies for remediation. ISRN Ecol. 2011, 2011, 402647. [CrossRef]

7. Giusquiani, P.L.; Patumi, M.; Businelli, M. Chemical composition of fresh and composted urban waste. Plant Soil 1989, 116, 278-282. [CrossRef]

8. Garcia, C.; Herna'ndez, T.; Costa, F. The influence of composting on the fertilizing value of aerobic sewage sludge. Plant Soil 1991, 139, 269-272. [CrossRef]

9. Whalen, J.K.; Hu, Q.; Liu, A. Compost applications increase water-stable aggregates in conventional and no-tillage systems. Soil Sci. Soc. Am. J. 2003, 67, 1842-1847. [CrossRef]

10. Larney, F.J.; Olson, A.F.; Miller, J.J.; DeMaere, P.R.; Zvomuya, F.; McAllister, T.A. Physical and chemical changes during composting of wood chip-bedded and straw-bedded beef cattle feedlot manure. J. Environ. Qual. 2008, 37, 725-735. [CrossRef] [PubMed]

11. Wagh, S.P.; Gangurde, S.V. Effect of Cow-Dung Slurry and Trichoderma spp. on Quality and Decomposition of Teak and Bamboo Leaf Compost. Res. J. Agric. For. Sci. 2015, 3, 1-4.

12. Hashimoto, S.; Matsuura, T.; Nanko, K.; Linkov, I.; Shaw, G.; Kaneko, S. Predicted spatio-temporal dynamics of radiocesium deposited onto forests following the Fukushima nuclear accident. Sci. Rep. 2014. [CrossRef] [PubMed]

13. Airborne Monitoring Results on 28 December 2012; The "Extension Site of Distribution Map of Radiation Dose, etc., /Digital Japan" as the Source of the Map. Available online: http://ramap.jmc.or.jp/map/eng/ (accessed on 26 October 2015). 
14. Cooper, J.A. Factors determining the ultimate detection sensitivity of $\mathrm{Ge}(\mathrm{Li})$ gamma-ray spectrometers. Nucl. Instrum. Methods 1970, 82, 273-277. [CrossRef]

15. Ministry of Health, Labour and Welfare. Japan Manual of Radioactivity Measurement for Food in Emergencies. Available online: http://www.mhlw.go.jp/stf/houdou/2r9852000001558eimg/ 2r98520000015cfn.pdf (accessed on 26 October 2015). (In Japanese)

16. USCC (United States Composting Council); Thompson, W.H.; Millner, P.D.; Watson, M.E.; Leege, P.B. (Eds.) Test Methods for the Examination of Composting and Compost (TMECC); US Composting Council: Holbrook, NY, USA, 2002.

17. Yamaki, A. A rapid UV absorption method for determination of nitrate in soil extracts. Jpn. J. Soil Sci. Plant Nutr. 2003, 74, 195-197.

18. Editorial Committee of Soil Environmental Analysis. Soil Environmental Analysis, 4th ed.; Hakuyu Press: Tokyo, Japan, 2008.

19. Thomas, G.W. Exchangeable Cations. In Methods of Soil Analysis: Part 2, Chemical and Microbiological Properties; Page, A.L., Ed.; American Society of Agronomy and Soil Science Society of America: Madison, WI, USA, 1982; pp. 159-165.

20. Byrne, E. Chemical Analysis of Agricultural Materials; An Foras Taluntais: Dublin, Ireland, 1979; pp. 1-194.

21. Belyaeva, O.N.; Haynes, R.J. Chemical, microbial and physical properties of manufactured soils produced by co-composting municipal green waste with coal fly ash. Bioresour. Technol. 2009, 100, 5203-5209. [CrossRef] [PubMed]

22. Culley, J.L.B. Density and compressibility. In Soil Sampling and Methods of Analysis; Carter, M.R., Ed.; Lewis Publishers: Boca Raton, FL, USA, 1993; pp. 529-539.

23. Blake, G.R.; Hartage, K.H. Particle density. In Methods of Soil Analysis Part 1, 2nd ed.; Agronomy Monograph No. 9; Klute, A., Ed.; American Society of Agronomics and Soil Science Society of America: Madison, WI, USA, 1986; pp. 377-382.

24. Hendershot, W.H.; Lalande, H.; Duquette, M. Soil reaction and exchangeable acidity. In Soil Sampling and Methods of Analysis; Carter, M.R., Ed.; Lewis Publishers: Boca Raton, FL, USA, 1993; pp. 141-146.

25. Bower, C.A.; Wilcox, L.V. Soluble salts. In Methods of Soil Analysis. Part 2. Chemical and Microbiological Properties; American Society of Agronomy, Soil Science Society of America: Madison, WI, USA, 1965; pp. 933-951.

26. Harada, H.; Amaha, K.; Abe, Y.; Kojima, Y.; Sunaga, Y.; Kawachi, T. Transfer factor of radioactive cesium to forage corn (Zea mays L.) from soil to which contaminated farmyard manure had been applied. Soil Sci. Plant Nutr. 2014, 60, 782-789. [CrossRef]

27. Alexakhin, R.M. Countermeasures in agricultural production as an effective means of mitigating the radiological consequences of the Chernobyl accident. Sci. Total Environ. 1993, 137, 9-20. [CrossRef]

28. Entry, J.A.; Watrud, L.S.; Reeves, M. Influence of organic amendments on the accumulation of ${ }^{137} \mathrm{Cs}$ and ${ }^{90} \mathrm{Sr}$ from contaminated soil by three grass species. Water Air Soil Pollut. 2001, 126, 385-398. [CrossRef]

29. Verdonck, O. Compost specifications. In Proceedings of the International Symposium on Composting \& Use of Composted Material in Horticulture, Scotland, UK, 5-11 April 1997; Volume 469, pp. 169-178.

30. Neklyudov, A.D.; Fedotov, G.N.; Ivankin, A.N. Aerobic processing of organic waste into composts. Appl. Biochem. Microbiol. 2006, 42, 341-353. [CrossRef]

31. Soumare, M.; Tack, F.M.G.; Verloo, M.G. Effects of a municipal solid waste compost and mineral fertilization on plant growth in two tropical agricultural soils of Mali. Bioresour. Technol. 2003, 86, 15-20. [CrossRef]

32. Makan, A.; Assobhei, O.; Mountadar, M. Effect of initial moisture content on the in-vessel composting under air pressure of organic fraction of Municipal solid waste in Morocco. Iran. J. Environ. Health 2013, 10, 3. [CrossRef] [PubMed]

33. Mulligan, C.N. Environmental applications for bio surfactants. Environ. Pollut. 2005, 133, 183-198. [CrossRef] [PubMed]

34. Simandi, P.; Takayanagi, M.; Inubushi, K. Changes in the $\mathrm{pH}$ of two different composts are dependent on the production of organic acids. Soil Sci. Plant Nutr. 2005, 51, 771-774. [CrossRef]

35. Li, R.; Wang, J.J.; Zhang, Z.; Shen, F.; Zhang, G.; Li, X.; Xiao, R. Nutrients transformation during composting of pig manure with bentonite. Bioresour. Technol. 2012, 121, 362-368. [CrossRef] [PubMed]

36. Liu, K.; Price, G.W. Evaluation of three composting systems for the management of spent coffee grounds. Bioresour. Technol. 2011, 102, 7966-7974. [CrossRef] [PubMed] 
37. Villar, M.C.; Beloso, M.C.; Acea, M.J.; Cabaneiro, A.; González-Prieto, S.J.; Díaz-Ravina, M.; Carballas, T. Physical and chemical characterization of four composted urban refuses. Bioresour. Technol. 1993, 45, 105-113. [CrossRef]

38. Huang, G.F.; Wong, J.W.C.; Wu, Q.T.; Nagar, B.B. Effect of C/N on composting of pig manure with sawdust. Waste Manag. 2004, 24, 805-813. [CrossRef] [PubMed]

39. Wang, P.; Changa, C.M.; Watson, M.E.; Dick, W.A.; Chen, Y.; Hoitink, H.A.J. Maturity indices for composted dairy and pig manures. Soil Biol. Biochem. 2004, 36, 767-776. [CrossRef]

40. Harada, Y.; Inoko, A. The measurement of the cation-exchange capacity of composts for the estimation of the degree of maturity. Soil Sci. Plant Nutr. 1980, 26, 127-134. [CrossRef]

41. Zhang, L.; Sun, X. Effects of rhamnolipid and initial compost particle size on the two-stage composting of green waste. Bioresour. Technol. 2014, 163, 112-122. [CrossRef] [PubMed]

42. Fang, M.; Wong, J.; Ma, K.K.; Wong, M.H. Co-composting of sewage sludge and coal fly ash: Nutrient transformations. Bioresour. Technol. 1999, 67, 19-24. [CrossRef]

43. Rodriguez-Kabana, R.; Morgan-Jones, G.; Chet, I. Biological control of nematodes: Soil amendments and microbial antagonists. Plant Soil 1987, 100, 237-247. [CrossRef]

44. Mendonça Costa, M.S.S.; Cestonaro, T.; de Mendonça Costa, L.A.; Rozatti, M.A.T.; Carneiro, L.J.; Pereira, D.C.; Lorin, H.E.F. Improving the nutrient content of sheep bedding compost by adding cattle manure. J. Clean. Prod. 2015, 86, 9-14. [CrossRef]

45. Nishanth, D.; Biswas, D.R. Kinetics of phosphorus and potassium release from rock phosphate and waste mica enriched compost and their effect on yield and nutrient uptake by wheat (Triticum estivum). Bioresour. Technol. 2008, 99, 3342-3353. [CrossRef] [PubMed]

46. Ros, M.; Garcia, A.; Herandez, T. A full-scale study of treatment of pig slurry by composting: Kinetic changes in chemical and microbial properties. Waste Manag. 2006, 26, 1108-1118. [CrossRef] [PubMed]

47. Brito, L.M.; Coutinho, J.; Smith, S.R. Methods to improve the composting process of the solid fraction of dairy cattle slurry. Bioresour. Technol. 2008, 99, 8955-8960. [CrossRef] [PubMed]

48. Das, M.; Uppal, H.S.; Singh, R.; Beri, S.; Mohan, K.S.; Gupta, V.C.; Adholeya, A. Co-composting of physic nut (Jatropha curcas) deoiled cake with rice straw and different animal dung. Bioresour. Technol. 2011, 102, 6541-6546. [CrossRef] [PubMed]

49. Chaoui, H.I.; Zibilske, L.M.; Ohno, T. Effects of earthworm casts and compost on soil microbial activity and plant nutrient availability. Soil Biol. Biochem. 2003, 35, 295-302. [CrossRef]

50. Mylavarapu, R.S.; Zinati, G.M. Improvement of soil properties using compost for optimum parsley production in sandy soils. Sci. Hortic. 2009, 120, 426-430. [CrossRef]

51. Courtney, R.G.; Mullen, G.J. Soil quality and barley growth as influenced by the land application of two compost types. Bioresour. Technol. 2008, 99, 2913-2918. [CrossRef] [PubMed]

52. Hoshino, Y.; Higashi, T.; Ito, T.; Komatsuzaki, M. Tillage can reduce the radiocesium contamination of soybean after the Fukushima Dai-ichi nuclear power plant accident. Soil Tillage Res. 2015, 153, 76-85. [CrossRef]

53. Epstein, E.; Taylor, J.M.; Chaney, R.L. Effects of sewage sludge and sludge compost applied to soil on some soil physical and chemical properties. Environ. Qual. 1976, 5, 422-426. [CrossRef]

54. Alvarez, M.A.B.; Gagne, S.; Antoun, H. Effect of compost on rhizosphere micro flora of the tomato and on the incident of plant-growth promoting rhizobacteria. Appl. Eniron. Microbiol. 1995, 61, 194-199.

55. Cherif, H.; Ayari, F.; Ouzari, H.; Marzorati, M.; Brusetti, L.; Jedidi, N.; Hassen, A.; Daffonchio, D. Effects of municipal solid waste compost, farmyard manure and chemical fertilizers on wheat growth, soil composition and soil bacterial characteristics under Tunisian arid climate. Eur. J Soil Biol. 2009, 45, 138-145. [CrossRef]

56. Keeling, A.; McCallum, R.; Beckwitn, C. Mature green waste compost enhances growth and nitrogen uptake in wheat (Triticum aestivum L.) and oilseed rape (Brassica napus L.) through the action of water-extractable factors. Bioresour. Technol. 2003, 90, 127-132. [CrossRef]

(c) 2016 by the authors; licensee MDPI, Basel, Switzerland. This article is an open access article distributed under the terms and conditions of the Creative Commons Attribution (CC-BY) license (http://creativecommons.org/licenses/by/4.0/). 